\title{
Peter J. Boettke, Alexander William Salter, and Daniel J. Smith: Money and the rule of law: generality and predictability in monetary institutions
}

\author{
Cambridge University Press, 2021
}

\author{
Carl E. Walsh ${ }^{1}$
}

Published online: 16 November 2021

(c) National Association for Business Economics 2021

The years since the Global Financial Crisis have been busy ones for central bankers. The U.S. Federal Reserve, for example, has expanded its balance sheet from just under $6 \%$ of nominal GDP in 2007 to more than 35\% of GDP in 2021, engaged in a massive provision of short-term liquidity to financial markets, kept its policy rate at virtually zero for most of the past 13 years, started paying interest on reserves, adopted a $2 \%$ inflation target, dropped the $2 \%$ target to adopt an average inflation rate target, purchased commercial paper and corporate bonds, and lent directly to small businesses.

In Money and the Rule of Law: Generality and Predictability in Monetary Institutions, Peter J. Boettke, Alexander William Salter, and Daniel J. Smith make it clear that they do not like these Fed actions. They don't like them because they reflect discretionary acts by an "unlawful" central bank unconstrained by any "true monetary policy rule." As they put it: "Current monetary arrangements represent not the rule of law, but the rule of central bankers" (p. 147). And "Without the rule of law binding to the mast the hands of monetary policymakers, they cannot help but dash the macroeconomy on the rocks in response to the urge for technocratic tinkering in ordinary times, moral hazard-inducing bailouts during extraordinary times, and passive accommodation to perpetual deficits in both" (p. 155).

They build their case against discretion and for rules by highlighting two problems policymakers inevitably face when engaging in discretionary policy: knowledge problems (e.g., the inability to know the true model of the economy and the dependence of policy on poorly measured or conceptually unobservable constructs such as r-star or $\mathrm{u}$-star), and incentive problems (e.g., the perverse incentives created by

Carl E. Walsh

walshc@ucsc.edu

1 University of California, Santa Cruz, USA institutional structures, political pressure, and special interest lobbying). Both problems are important, and both have been studied intensively by economists.

The authors' discussion of knowledge problems is marred, however, by their dated view of monetary policy, which they characterize as controlling the monetary base "to continuously, and presciently, discern and meet the public's demand for money" (p. 37). In fact, the monetary base has, by and large, disappeared from academic and central bank research on monetary policy, as well as from the actual practice of monetary policy. The failure to adopt a more modern macro perspective detracts from the generality of the book's arguments. This is unfortunate, as the authors provide an excellent list of the knowledge problems that led money aggregates to be dropped from most monetary policy analysis.

Boettke, Salter, and Smith correctly stress that policymakers respond to the incentives created by the institutional structure within which they operate. They accuse economists of ignoring this issue. There is, however, a huge literature that focuses on exactly this issue. ${ }^{1}$ While economists often assume policymakers are benevolent "Ramsey planners," immune from any incentive problems, the resulting Ramsey policies are an idealization, like perfect competition, designed precisely to provide a benchmark for studying how discretionary policymaking may distort policy outcomes. From the academic work on the Great Inflation of the 1970s to the debate over average inflation targeting, issues of credibility, the gains from commitment, and the costs of discretion have had at their core the idea that optimal policies may be difficult (or impossible) to achieve because of inherent incentives for policymakers to promise one thing but deliver another.

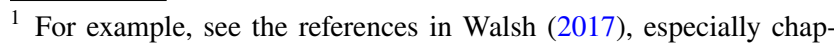
ters 6 and 8 .
} 
Incentives are shaped by institutions, and the authors appeal to the philosophical framework of classical liberalism and the views of Friedrich Hayek, Milton Friedman, and James Buchanan to emphasize the importance of the institutional structure within which policy is made and to stress that economists have paid too little attention to issues of institutional design. To illustrate incentive problems, the authors carefully document many examples of the political pressures the Fed has faced as different interest groups seek policies they see as favorable. However, attempts to influence the Fed need not mean that these pressures have been successful. Hess and Shelton (2016), cited in a footnote (p. 70), find no evidence that political pressures affected Fed policy between the mid-1980s and the end of their sample in 2005. This is the period known as the Great Moderation, when the Fed displayed more "rule-like behavior." But rulelike behavior allows for deviations from the rule (i.e., discretion). And limiting discretion is not what the authors seek; their objective is to eliminate discretion. "What this means for monetary institutions is that central bankers should be bound by rules rather than permitted discretion" (p. 12, emphasis in original).

I was expecting, therefore, that the authors would offer some insights into what institutional structure should replace current monetary policy frameworks, and that would succeed in eliminating discretion, while also promoting low and stable inflation and overall macroeconomic and financial stability. One searches the book in vain for any such practical insights. Instead, the authors simply propose that monetary policy should be governed by a "true monetary policy rule." And "Instead of discretion, monetary authorities ought to be constrained by a 'higher law' that the monetary authority itself cannot change and is simple enough to admit minimal interpretive latitude" (p. 147). A true monetary policy rule "...must actually constrain the operation of monetary policy; and there must be negative consequences for those who break them" (p. 152). Perhaps they have in mind a Congressionally-mandated strict version of Friedman's $k$-percent money growth rate rule, or a Taylor rule, as contained in legislation proposed but never adopted by the 113th Congress in $2014 .{ }^{3}$ Unfortunately, the authors never describe who would decide on this "true rule", what such a

\footnotetext{
2 Whether the latter was responsible for the former is open to debate. Stock and Watson (2003), for example, attribute only a small part of the decline in inflation and output volatility in the Great Moderation to improved monetary policy.

${ }^{3}$ During hearings before the House Financial Services Committee on H.R. 5018 (July 16, 2014), then Federal Reserve Chair Janet Yellen testified that "It would be a grave mistake for the Fed to commit to conduct monetary policy according to a mathematical rule."
}

rule would look like, nor how policymakers would be held accountable for following it. ${ }^{4}$

To design such a rule, economists (technocratic tinkerers?) would need to assess the degree to which each potential rule would contribute to macroeconomic objectives relative to the consequences of eliminating discretion. These assessments would serve "as an input into democratic deliberations over what rules we will voluntarily adopt..." (p. 153, emphasis added). This seems both to ignore the knowledge problems involved in designing rules and to reveal a naive view of democratic deliberations at a time when, at least in the U.S., even simple public health measures during a pandemic spark sharp disagreement. Who exactly is the "we" who will be adopting these binding constraints? What mechanism could ensure that no one regrets enforcement of the rule? That there could be such a rule seems inconsistent with the authors' stress on special interests exerting pressures on central banks, as any actual rule would inevitably affect members of the public differently at different points of time. And any rule eliminating discretion would need to specify in advance how policy would respond during rare events (think of COVID-19 for example). Boettke, Salter, and Smith appear to view citizens as informed agents, well able to assess the relevant policy tradeoffs and the implications of alternative institutional structures for binding policy, much like the Ramsey policymaker the authors dismiss. One elite the authors decry-technocratic tinkerers-is replaced with another elite- those who define the rule.

Progress in thinking about policy rules must start with a clear statement of policy goals. Simply eliminating discretion cannot be a policy goal; at best, it is a strategy for achieving policy goals. ${ }^{5}$ For Boettke, Salter, and Smith, "sound money" is the goal, yet they offer no specific suggestions for a rule that would achieve sound money. Thomas Jordan, Chairman of the Governing Board of the Swiss National Bank, is much more explicit, defining three properties of an institutional structure consistent with sound money: (1) a clear mandate for the central bank, setting as its target the preservation of price stability and thus ensuring sound money; (2) protection from political influence by enshrining the independence of the central bank in law; and (3) healthy fiscal finances. ${ }^{6}$ Jordan's structure sounds much like inflation targeting, a form of "constrained discretion" as advocated by, for example Bernanke et al. (1998). But

\footnotetext{
${ }^{4}$ On this last point, the authors simply say, "There is some institutional technology that binds the hands of monetary policymakers in such a way that they cannot deviate from the rule" (p. 10).

${ }^{5}$ See Walsh (2015) for a comparison of policies based on goals and those based on rules. Dellas and Tavlas (2016) offer an interesting discussion of the debate between constrained discretion and rules.

6 Jordan (2020, p. 6).
} 
Boettke, Salter, and Smith do not want to constrain discretion, they want to eliminate discretion, dismissing inflation targeting as not a true rule. (p. 157).

Reading this book, one would think U.S. monetary policy has been a complete failure over the past 35 years. Yet if "sound money" is interpreted as delivering minimal fluctuations of the price level around a low trend rate of inflation, then recent experience would need to award the Fed high marks. Inflation has remained low and stable, ${ }^{7}$ the U.S. avoided another Great Depression after the Global Financial Crisis, and if the Fed's responses sowed the seeds of moral hazard, we have not seen another financial crisis yet. All this could easily change, and at the time of this writing, inflation has spiked-whether due to temporary supply disruptions caused by COVID-19 or as a signal of inflation and fiscal deficits out of control remains to be seen. If the authors are right that the Fed is unable to resist political pressure, then the coming months may offer a clear test of their hypothesis.

Regardless though, what the authors fail to do is offer practical solutions to the problems they identify. Ultimately, I was left wishing for some technocratic tinkerers to flesh out what a true monetary rule would look like, how it would perform in practice, and how policymakers could be held accountable for following it.

\section{References}

Bernanke, Ben S., Thomas Laubach, Frederic S. Mishkin, and Adam Posen. 1998. Inflation Targeting: Lessons from the International Experience. Princeton: Princeton University Press.
Dellas, Harris, and George S. Tavlas. 2016. Friedman and the Bernanke-Taylor Debate on Rules versus Constrained Discretion. Cato Journal 36 (2): 297-313. https://doi.org/10.7892/boris. 93171.

Hess, Gregory D., and Cameron Shelton. 2016. Congress and the Federal Reserve. Journal of Money, Credit and Banking 48 (4): 603-633.

Jordan, Thomas J. 2020. "What Constitutes Sound Money?" Economic Conference, Progress Foundation.

Stock, James H., and Mark W. Watson. 2003. Commentary: Has the Business Cycle Changed? Evidence and Explanations. Monetary Policy and Uncertainty 8: 9-56.

Walsh, Carl E. 2015. Goals and Rules in Central Bank Design. International Journal of Central Banking 11 (September): 295-352.

Walsh, Carl E. 2017. Monetary Theory and Policy, 4th ed. Cambridge, MA: The M.I.T. Press.

Publisher's Note Springer Nature remains neutral with regard to jurisdictional claims in published maps and institutional affiliations.

Carl E. Walsh is Distinguished Professor of Economics Emeritus at the University of California, Santa Cruz. He has held faculty appointments at Princeton University and Auckland University (New Zealand) and visiting appointments at UC Berkeley and Stanford. He is a former Senior Economist at the Federal Reserve Bank of San Francisco and has been a visiting scholar at the Federal Reserve Banks of Kansas City, Philadelphia, and San Francisco, and the Federal Reserve Board. From 1994 to 2000, he served on the Board of Editors of the American Economic Review and was co-editor of the International Journal of Central Banking from 2008 to 2012. Walsh is currently an Honorary Adviser to the Institute for Monetary and Economic Studies at the Bank of Japan. In addition to his academic publications, Walsh is the author of Monetary Theory and Policy, now in its fourth edition (The MIT Press 2017).
7 In fact, the squared deviation of year-over-year PCE inflation around a 2\% target from January 2003 to January 2020 was almost $30 \%$ lower than it was during the rule-like era from 1985 to 2002. 